\title{
Effects of Mg Doping at Different Positions in Li-Rich Mn-Based Cathode Material on Electrochemical Performance
}

\author{
Elena Makhonina ${ }^{1, *}$, Lidia Pechen ${ }^{1}$, Anna Medvedeva ${ }^{1}$, Yury Politov ${ }^{1}$, Aleksander Rumyantsev ${ }^{2}$, \\ Yury Koshtyal ${ }^{2}$, Vyacheslav Volkov ${ }^{1}$, Alexander Goloveshkin ${ }^{3}$ (D) and Igor Eremenko ${ }^{1, *}$
}

1 Kurnakov Institute of General and Inorganic Chemistry, Russian Academy of Sciences, 31 Leninsky pr., 119991 Moscow, Russia; lidia.s.maslennikova@gmail.com (L.P.); anna.ev.medvedeva@gmail.com (A.M.); polserv@mail.ru (Y.P.); svolkov77@gmail.com (V.V.)

2 Ioffe Institute, Russian Academy of Sciences, 26 Politekhnicheskaya ul., 194021 St. Petersburg, Russia; rumyantsev.amr@gmail.com (A.R.); yury.koshtyal@gmail.com (Y.K.)

3 Nesmeyanov Institute of Organoelement Compounds, Russian Academy of Sciences, 28 Vavilova ul., 119334 Moscow, Russia; golov-1@mail.ru

* Correspondence: evma@igic.ras.ru (E.M.); ilerem@igic.ras.ru (I.E.); Tel.: +7-903-143-17-38 (E.M.)

Citation: Makhonina, E.; Pechen, L.;

Medvedeva, A.; Politov, Y.;

Rumyantsev, A.; Koshtyal, Y.;

Volkov, V.; Goloveshkin, A.;

Eremenko, I. Effects of Mg Doping at

Different Positions in Li-Rich

Mn-Based Cathode Material on

Electrochemical Performance.

Nanomaterials 2022, 12, 156. https:// doi.org/10.3390/nano12010156

Academic Editor: Cheol-Min Park

Received: 3 December 2021

Accepted: 31 December 2021

Published: 3 January 2022

Publisher's Note: MDPI stays neutral with regard to jurisdictional claims in published maps and institutional affiliations.

Copyright: (C) 2022 by the authors. Licensee MDPI, Basel, Switzerland. This article is an open access article distributed under the terms and conditions of the Creative Commons Attribution (CC BY) license (https:// creativecommons.org/licenses/by/ $4.0 /)$.

\begin{abstract}
Li-rich Mn-based layered oxides are among the most promising cathode materials for next-generation lithium-ion batteries, yet they suffer from capacity fading and voltage decay during cycling. The electrochemical performance of the material can be improved by doping with $\mathrm{Mg}$. However, the effect of $\mathrm{Mg}$ doping at different positions (lithium or transition metals) remains unclear. $\mathrm{Li}_{1.2} \mathrm{Mn}_{0.54} \mathrm{Ni}_{0.13} \mathrm{Co}_{0.13} \mathrm{O}_{2}$ (LR) was synthesized by coprecipitation followed by a solid-state reaction The coprecipitation stage was used to introduce $\mathrm{Mg}$ in TM layers (sample LR-Mg), and the solid-state reaction (st) was used to dope $\mathrm{Mg}$ in Li layers ( $\mathrm{LR}-\mathrm{Mg}(\mathrm{st})$ ). The presence of magnesium at different positions was confirmed by XRD, XPS, and electrochemical studies. The investigations have shown that the introduction of $\mathrm{Mg}$ in TM layers is preferable in terms of the electrochemical performance. The sample doped with $\mathrm{Mg}$ at the TM positions shows better cyclability and higher discharge capacity than the undoped sample. The poor electrochemical properties of the sample doped with $\mathrm{Mg}$ at $\mathrm{Li}$ positions are due to the kinetic hindrance of oxidation of the manganese-containing species formed after activation of the $\mathrm{Li}_{2} \mathrm{MnO}_{3}$ component of the composite oxide. The oxide $\mathrm{LR}-\mathrm{Mg}(\mathrm{st})$ demonstrates the lowest lithium-ion diffusion coefficient and the greatest polarization resistance compared to LR and LR-Mg.
\end{abstract}

Keywords: Li-ion battery; cathode material; Li-rich oxide; $\mathrm{Mg}$ doping

\section{Introduction}

Lithium-ion batteries (LIBs) now dominate in portable electronic devices such as mobile phones, computers, cameras, etc., and the portable electronics market constantly grows. By 2030, the stationary and transportation energy storage markets combined are estimated to grow 2.5-4 terawatt-hours annually, approximately three to five times the current 800-gigawatt-hour market [1]. LIBs are considered to capture the majority of energy storage growth in all markets over at least the next 10 years. To meet those needs, especially for their use in batteries for electrical grids and hybrid and electric vehicles, current LIBs need first of all a higher energy density, cycling stability and safety. Cathode materials play a key role in the high-energy battery electrochemical performance. Among the wide variety of positive electrode materials for LIBs, only a few show enough potential for commercialization, and Li-rich and Ni-rich materials are clearly the most promising of those $[2,3]$.

Lithium-excess transition metal (TM) oxides $x \mathrm{Li}_{2} \mathrm{MnO}_{3} \cdot(1-x) \mathrm{LiMn}_{\mathrm{a}} \mathrm{Ni}_{\mathrm{b}} \mathrm{Co}_{\mathrm{c}} \mathrm{O}_{2}$ with a layered structure, so called Li-rich oxides, are considered to be attractive cathode materials because of their high specific capacity at the upper voltage $>4.5 \mathrm{~V}(>230-250 \mathrm{~mA} \mathrm{~h} / \mathrm{g})$ [4-7]. The 
$\mathrm{Li}_{2} \mathrm{MnO}_{3}$ component of Li-rich oxides has a unique oxygen redox activity that has attracted many researchers $[8,9]$. The anionic redox activity is due to overlapping atomic TM $\mathrm{d}$ orbitals and non-bonding $\mathrm{O} 2 \mathrm{p}$ orbitals, which can deliver extra electrons to the cationic $\mathrm{TM}^{(\mathrm{n}+1)+} / \mathrm{TM}^{\mathrm{n}+}$ redox center $[8,10]$. Compared to the axial $\mathrm{Li}-\mathrm{O}-\mathrm{TM}$ configurations centered on each $\mathrm{O}$ in $\mathrm{LiCoO}_{2}$ or $\mathrm{LiMn}_{\mathrm{a}} \mathrm{Ni}_{\mathrm{b}} \mathrm{Co}_{\mathrm{c}} \mathrm{O}_{2}(\mathrm{NMC})$, the octahedral $\mathrm{O}$ in Li-rich $\mathrm{NMC}$ additionally has an axial $\mathrm{Li}-\mathrm{O}-\mathrm{Li}$ configuration. Extraction of the labile oxygen electrons along the $\mathrm{Li}-\mathrm{O}-\mathrm{Li}$ configuration is the origin of oxygen oxidation and extra capacity beyond the TM redox capacity [11]. However, the oxygen redox reaction in Li-rich layered oxides usually results in $\mathrm{O}-\mathrm{O}$ dimerization $\left(2 \mathrm{O}^{2-} \rightarrow \mathrm{O}^{2 n-}\right)[12,13]$. This leads to $\mathrm{O}_{2}$ release, the formation of oxygen vacancies, and the migration of transition metal ions during charge-discharge, resulting in a poor cyclability, voltage decay, and safety problems for high-energy LIBs $[14,15]$. The migration of transition metals to the Li-layer hinders Li+ reinsertion and causes a large voltage hysteresis between charge and discharge [16,17]. To suppress the process of $\mathrm{O}-\mathrm{O}$ dimerization and gas release from the surface, many efforts have been undertaken, including surface coating [18], surface modification [19,20], element doping and co-doping with different elements [21], simultaneous surface coating and doping [22,23], and local symmetry tuning [24].

Doping seems to be one of the most effective modification methods to change the local atomic environment to consequently affect the oxygen redox reaction and electrochemical performance of Li-rich cathode materials. The doping of Li-rich oxides with $\mathrm{Na}, \mathrm{K}, \mathrm{Mg}$, $\mathrm{Al}, \mathrm{Fe}, \mathrm{Co}, \mathrm{Ru}$, and other elements have been found to stabilize capacity and mitigate the discharge-voltage decay in these materials [14,25]. There are several studies dealing with the effects of doping Li-rich oxides with $\mathrm{Mg}$. Considering that matching the ionic radii, $\mathrm{Mg}^{2+}$ with the ionic radius similar to that of $\mathrm{Li}^{+}$and larger than those of transition metal ions (0.69 $\AA, 0.545 \AA$, and $0.53 \AA$ for $\mathrm{Ni}^{2+}, \mathrm{Co}^{3+}$, and $\mathrm{Mn}^{4+}$, respectively) would be more suitable to occupy the sites in Li layers rather than in TM layers. Nevertheless, the authors of [26] have been studied the effect of $10 \mathrm{Li}$-site cationic dopants $(\mathrm{Mg}, \mathrm{Ti}, \mathrm{V}$, $\mathrm{Nb}, \mathrm{Fe}, \mathrm{Ru}, \mathrm{Co}, \mathrm{Ni}, \mathrm{Cu}, \mathrm{Al}$ ) on the electrochemical properties of $\mathrm{Li}_{2} \mathrm{MnO}_{3}$ and $\mathrm{LiMnO}_{2}$ using density functional theory (DFT). According to the DFT calculations, Mn sites are thermodynamically favorable over Li-site doping. However, the small thermodynamic barriers between both configurations can be easily overcome during the material synthesis and/or the extraction/insertion of Li during the cycling process of the battery. Indeed, the examples of doping magnesium at both the Li and TM positions are known, such as the studies [27,28], where Mg was doped at Li positions and [29-31], where Mg was doped at TM positions. Mainly, Mg doping leads to a better cyclability of Li-rich oxides, regardless of the substituted position. At the same time, it has been reported that site-dependent doping has different impacts on the electrochemical properties of cathode materials [32]. It is of interest to compare the Li-rich oxides of the same composition doped with $\mathrm{Mg}$ at different positions.

In this work, we studied Mg-doped Li-rich layered cathode materials synthesized by different procedures with the aim to introduce $\mathrm{Mg}$ ions at different positions, namely, in TM- and Li layers, and compare their electrochemical properties. The oxides were synthesized by coprecipitation followed by a solid-state reaction with a lithium source. Magnesium ( $2 \mathrm{~mol} \%$ of the Co amount) was added at the precipitation step (LR-Mg oxide) and in the solid-state reaction ( $2 \mathrm{~mol} \%$ of the Li amount, LR-Mg(st) oxide). For comparison, $\mathrm{Li}$-rich oxide of the same composition except magnesium, $\mathrm{Li}_{1.2} \mathrm{Mn}_{0.54} \mathrm{Ni}_{0.13} \mathrm{Co}_{0.13} \mathrm{O}_{2}$ (LR), was obtained. The materials were characterized by X-ray powder diffraction (XRD) with Rietveld refinement, scanning electron microscopy (SEM) with local X-ray energy dispersive spectroscopy (EDX), transmission electron microscopy (TEM) with selected-area electron diffraction (SAED), X-ray photoelectron spectroscopy (XPS), Brunauer-Emmett-Teller surface area measurements, charge-discharge tests, and galvanostatic intermittent titration (GITT). The LR-Mg and LR-Mg(st) oxides reveal different behavior when tested as half-cell Li-ion cathodes. LR-Mg shows a better cyclability and rate performance than LR-Mg(st) or the reference sample. 


\section{Materials and Methods}

\subsection{Synthesis}

The Li-rich oxide materials were synthesized by coprecipitation followed by a solidstate reaction with a lithium source. The starting reagents for all synthetic procedures were $\mathrm{Ni}\left(\mathrm{NO}_{3}\right)_{2} \cdot 6 \mathrm{H}_{2} \mathrm{O}\left(99.9 \%\right.$, ABCR, Karlsruhe, Germany), $\mathrm{Co}\left(\mathrm{NO}_{3}\right)_{2} \cdot 6 \mathrm{H}_{2} \mathrm{O}(99 \%$, Acros Organics, Geel, Belgium), $\mathrm{Mn}\left(\mathrm{NO}_{3}\right)_{2} \cdot 4 \mathrm{H}_{2} \mathrm{O}$ (98\% Alfa Aesar, Kandel, Germany), and $\mathrm{Mg}\left(\mathrm{NO}_{3}\right)_{2} \cdot 6 \mathrm{H}_{2} \mathrm{O}\left(98 \%\right.$, Alfa Aesar), $\mathrm{LiOH} \cdot \mathrm{H}_{2} \mathrm{O}$ (99+\%, Sigma-Aldrich, Saint Louis, MO, USA), $\mathrm{MgO}$ (97\%, Chimmed, Moscow, Russia), $\mathrm{Na}_{2} \mathrm{CO}_{3}$ (98\%, Chimmed), $\mathrm{NH}_{4} \mathrm{OH}(98 \%$, Chimmed). All the reagents were used as received. For the precursor synthesis, a mixed aqueous solution of manganese, nickel and cobalt nitrates in appropriate amounts (including magnesium nitrate for the synthesis of LR-Mg sample) with a total concentration of $2.0 \mathrm{~mol} \mathrm{~L}^{-1}$ was prepared. The solution obtained and an aqueous solution of a precipitator $\left(\mathrm{Na}_{2} \mathrm{CO}_{3}, 2.0 \mathrm{~mol} \mathrm{~L}{ }^{-1}\right.$ and $\left.\mathrm{NH}_{4} \mathrm{OH}, 0.3 \mathrm{~mol} \mathrm{~L}^{-1}\right)$ were added simultaneously into a reactor using peristaltic pumps. The synthesis was carried out under a $\mathrm{CO}_{2}$ atmosphere. The $\mathrm{pH}$ value, reaction temperature, and stirring speed were kept at $7.5,60{ }^{\circ} \mathrm{C}$, and $1000 \mathrm{rpm}$, respectively. The precursor suspension thus obtained was stored for $15-16 \mathrm{~h}$. Then, the carbonate precursor was washed with deionized water, acetone, and diethyl ether, dried at $110^{\circ} \mathrm{C}$ in an argon flow for $18-20 \mathrm{~h}$, and thoroughly mixed with $\mathrm{LiOH} \cdot \mathrm{H}_{2} \mathrm{O}$ in an appropriate amount. A lithium excess ( $3 \mathrm{~mol} \%$ ) was used to compensate for lithium losses during sintering. For the synthesis of LR-Mg(st) oxide, $\mathrm{MgO}$ was added at the solid-state stage. The powders obtained were annealed in air at $480^{\circ} \mathrm{C}$ for $6 \mathrm{~h}$ and at $900^{\circ} \mathrm{C}$ for $12 \mathrm{~h}$. In the course of annealing, the mixtures were ground several times in an agate mortar.

\subsection{Methods}

The morphology, microstructure and element distribution of the Li-rich materials were studied using scanning electron microscopy (SEM, NVision-40, Carl Zeiss, Oberkochen, Germany) with energy dispersive $\mathrm{X}$-ray spectroscopy (EDX) and transmission electron microscopy (TEM, JEOL JEM 2100, Peabody, MA, USA, E = 200 kV) with EDX analysis. Selected-area electron diffractions (SAED) were taken. Particle size distribution was measured with the use of an Analysette 22 MicroTec Plus laser particle sizer (Idar-Oberstein, Germany). The Fraunhofer model was used for data analysis. The metal contents in the oxides prepared were measured by inductively coupled plasma mass-spectrometry (ICP-MS) with an Agilent 7500ce system (Santa Clara, CA, USA).

The X-ray powder diffraction (XRD) measurements were performed at room temperature in the $\Theta / 2 \Theta$ scan mode $\left(2 \Theta\right.$ range of $5^{\circ}-80^{\circ}, 0.02^{\circ}$ scan step) using diffractometers Bruker D8 Advance (CuK $\alpha$ radiation) and Bruker D8 Advance Vario (CuK $\alpha 1$, Ge monochromator, LynxEye position-sensitive detector, Billerica, MA, USA). The data were collected with the use of the Bruker DIFFRACplus program package. The analysis was performed with the EVA and TOPAS software packages. The diffraction patterns were refined by the Rietveld method. The crystallite sizes were estimated by using Williamson-Hall analysis.

The X-ray photoelectron spectroscopy (XPS) measurements were performed using a PHI5000 VersaProbe II instrument (Kanagawa, Japan) applying a monochromatic, microfocused, scanning Al K $\alpha$ X-ray source (50 Wt, $1486.6 \mathrm{eV}$ ) with $200 \mu \mathrm{m}$ spot size. The K-Alpha charge compensation system was used during analysis. The XPS data were collected from the area of $800 \times 400 \mu \mathrm{m}^{2}$ at a pass energy of $23.5 \mathrm{eV}$ with a step size of $0.2 \mathrm{eV}$ for C1s, O1s, Mn3s; and at a pass energy of $29.35 \mathrm{eV}$ with a step size of $0.25 \mathrm{eV}$ for Mn2p, Co2p3, Ni2p3.

The specific surface areas $\left(S_{\mathrm{BET}}\right)$ of the samples were measured by low-temperature nitrogen adsorption with a Katakon ATX-06 analyzer (Novosibirsk, Russia). The samples were degassed at $200{ }^{\circ} \mathrm{C}$ in a dry helium flow for $35 \mathrm{~min}$. The specific surface areas of the samples were calculated from the adsorption isotherms using the Brunauer-Emmett-Teller equation (BET). 


\subsection{Electrochemical Measurements}

Electrochemical studies were carried out in CR2032 coin-type cells with a Neware BTS CT-4008W-5V10mA battery testing system using at least three to five cells per sample. The cathodes were fabricated from a mixture of the active material, carbon black (Super C65, Timcal, Bodio, Switzerland), and polyvinylidene difluoride (PVDF) as a binder at the ratio of 92:3:5 wt \%. N-methylpyrrolidone (NMP) was used as a solvent. The active material loadings were equal, averaging $5-7 \mathrm{mg} \mathrm{cm}^{-2}$. The separator was Celgard 2325 (2 layers); the negative electrode was made of metallic lithium foil; and the electrolyte was TC-E918 (Tinci, Guangzhou, China). The electrode preparation is described in more detail elsewhere [33]. Galvanostatic charge-discharge tests were carried out in a voltage range of 2.5-4.7 $\mathrm{V}$ at room temperature at different current densities. Before cycling in this range, the high-voltage monoclinic phase was activated at a current density of $20 \mathrm{~mA} / \mathrm{g}$ as follows: two cycles in the range of $2.5-4.3 \mathrm{~V}$, then two cycles at $2.5-4.5 \mathrm{~V}$, and two cycles at $2.5-4.6 \mathrm{~V}$.

Galvanostatic intermittent titration (GITT) was performed during discharge processes to determine the lithium-ion diffusion coefficient $\left(D_{L i+}\right)$, and the polarization $\left(R_{\text {pol }}\right)$ and ohmic $\left(R_{\text {ohm. }}\right)$ resistance values. The samples were discharged at a constant current of $100 \mathrm{~mA} \mathrm{~g}^{-1}$ for $8 \mathrm{~min}$, succeeded by the current interruption (relaxation time) for $30 \mathrm{~min}$, which was sufficient to achieve the equilibrium voltage value. $D_{L i+}$ was determined using the GITT results according to Equation (1), as introduced by Weppner [34-36].

$$
D_{L \mathrm{i}+}=\frac{4}{\pi \tau}\left(\frac{m V_{m}}{M S}\right)^{2}\left(\frac{\Delta E_{S}}{\Delta E_{t}}\right)^{2},\left(\tau \triangleleft \triangleleft \frac{L^{2}}{D_{L i+}}\right)
$$

where:

$D_{\mathrm{Li+}}$-lithium-ion diffusion coefficient $\left(\mathrm{cm}^{2} / \mathrm{s}\right)$;

$\tau$-charge/discharge time of one GITT step (s);

$m$ - the active material weight $(\mathrm{g})$;

$V_{m}$ - the molar volume of the sample $\left(\mathrm{cm}^{3} / \mathrm{mol}\right)$;

$M$ - the atomic weight $(\mathrm{g} / \mathrm{mol})$;

$\mathrm{S}$ - the area of the sample-electrolyte interface $\left(\mathrm{cm}^{2}\right)$;

$\Delta E_{S}$ - the voltage difference between the initial discharge voltage and the voltage after relaxation; $\Delta E_{t}$ - the voltage change during one GITT step;

$L$-the sample thickness $(\mathrm{cm})$.

From the GITT results, we estimated the resistance values by the following procedure. At first, the voltage was measured at the end of each discharge step (U1). Then, the cut-off voltage was measured immediately after the current interruption (U2), and at the end of the relaxation time (U3). The cell resistances were calculated from the voltage differences between $U 2$ and $U 1\left(R_{\text {ohm. }}\right)$, and $U 3$ and $U 2\left(R_{\text {pol. }}\right)$ according to Equation (2) and Equation (3), respectively.

$$
\begin{aligned}
& R_{o h m .}=\frac{U 2-U 1}{I} \\
& R_{\text {pol. }}=\frac{U 3-U 2}{I}
\end{aligned}
$$

where:

I-discharge current (A).

\section{Results and Discussion}

In the comparative investigation, we used the Li-rich composition $\mathrm{Li}_{1.2} \mathrm{Mn}_{0.54} \mathrm{Ni}_{0.13} \mathrm{Co}_{0.13} \mathrm{O}_{2}$, which can be written in another notation as $0.5 \mathrm{Li}_{2} \mathrm{MnO}_{3} \cdot 0.5 \mathrm{LiMO}_{2}\left(\mathrm{M}=\mathrm{Mn}_{0.333} \mathrm{Ni}_{0.333} \mathrm{Co}_{0.333}\right)$. To obtain LR-Mg oxide, magnesium nitrate was added during the precipitation of the carbonate precursor at the expense of cobalt ( $2 \mathrm{~mol} \%)$. To obtain LR-Mg(st), magnesia was added together with lithium hydroxide in the solid-state reaction $(2 \mathrm{~mol} \%$ of the 
Li amount). The oxide compositions determined by inductively coupled plasma mass spectrometry (ICP-MS) are close to those preset in the synthesis (Table S1).

The SEM images of LR-Mg, LR-Mg(st), LR, and the precursor for LR (PR) are shown in Figure 1.

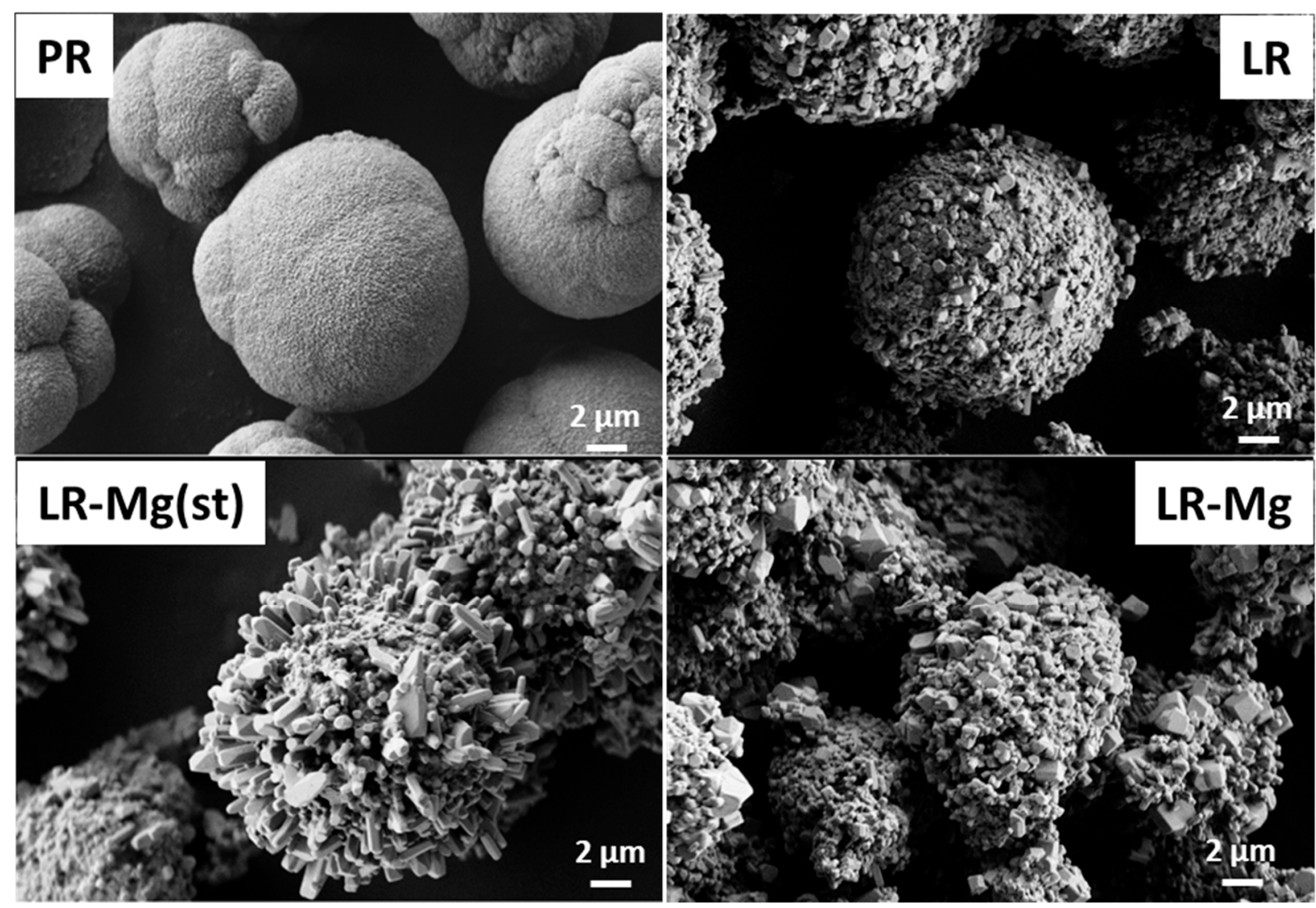

Figure 1. SEM images of the carbonate precursor for LR (PR) and of LR; LR-Mg; and LR-Mg(st) oxides (sample names are shown in the figures).

All the oxides are sphere-like agglomerates consisting of primary particles $200-500 \mathrm{~nm}$ in size. The oxides maintained the precursor morphology. LR and LR-Mg oxides have narrow particle size distributions that are very close to each other. The LR$\mathrm{Mg}(\mathrm{st})$ agglomerates and primary particles were characterized by a wider range of sizes (Figure S1). In addition, $\mathrm{LR}-\mathrm{Mg}$ (st) contains large particles up to $4-5 \mu \mathrm{m}$ in size. The element distribution EDX maps of LR-Mg and LR-Mg(st) (Figure S2) show that all the elements, including magnesium, were evenly distributed over the particle surface of both oxides.

The X-ray powder diffraction spectra of the materials obtained were typical for Li-rich oxides [37]. No additional XRD peaks were detected upon Mg doping, indicating the absence of any impurity phase. The XRD peaks can be indexed based on a cell with trigonal $(R \overline{3} m)$ or monoclinic $(C 2 / m)$ symmetry. According to our previous investigations of Li-rich oxides of the same composition using TEM with local electron diffraction [38], the oxides contained both structurally integrated phases: trigonal and monoclinic. This agreed with a large body of the literature $[3,37,39]$. Figure 2 presents the data of the TEM/SAED analysis of oxide LR. 


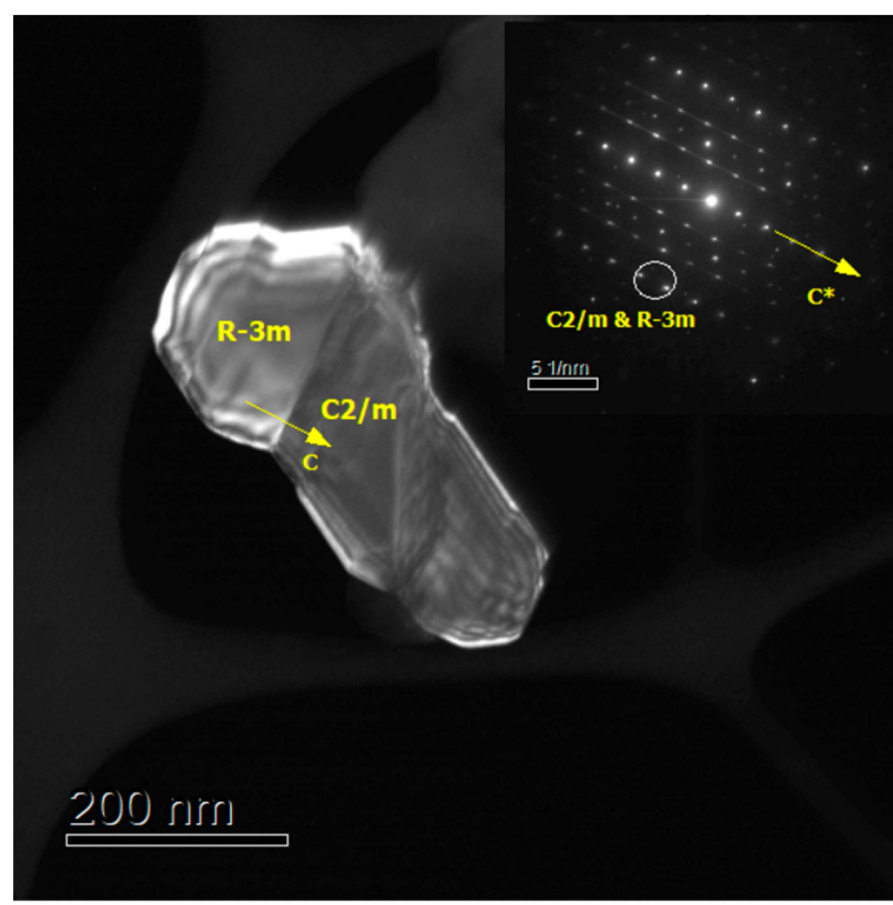

(a)

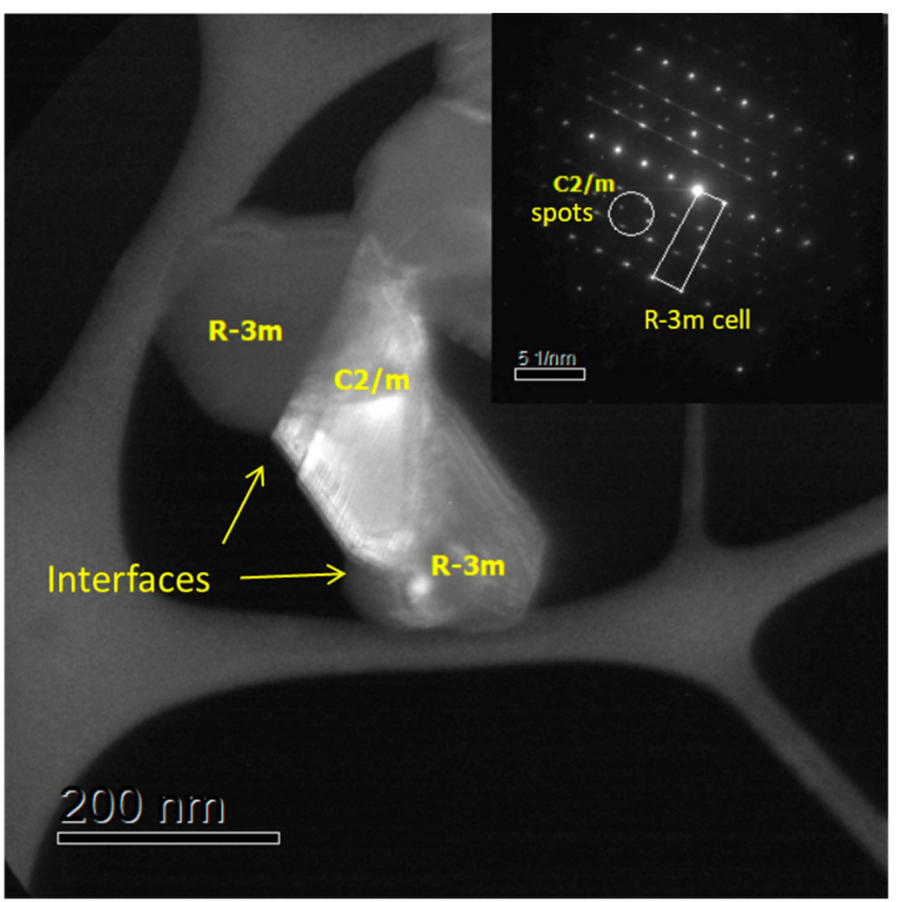

(b)

Figure 2. Results of TEM study of the reference sample $\mathrm{Li}_{1.2} \mathrm{Mn}_{0.54} \mathrm{Ni}_{0.13} \mathrm{Co}_{0.13} \mathrm{O}_{2}$ (LR): (a,b) DF images of a grain with intergrowth of crystals taken with the reflections marked with circles in SAED patterns; SAED patterns along the $(100)_{\mathrm{m}}$ zone are shown in the inserts.

Figure 2 demonstrates an evidence of intergrowth of trigonal $(R \overline{3} m)$ and monoclinic $(\mathrm{C} 2 / \mathrm{m})$ phases at nanoscale. Selected-area electron diffractions clearly showed the reflections of monoclinic and trigonal phases. A grain consisted of nanodomains was taken with the reflections marked with circles in the SAED patterns, which are very important to distinguish the $R \overline{3} m$ and $C 2 / m$ phases. The weak $C 2 / m$ superstructure spots, as observed and encircled in the SAED pattern of Figure $2 b$, usually appear to be very weak in XRD powder patterns. Therefore, taking into account that the $C 2 / m$ group appears to be a subgroup of the $R \overline{3} m$ group, we may try to neglect these superstructure spots by fitting a monoclinic phase with the trigonal $R \overline{3} m$ space group in the simplified XRD Rietveld refinement presented below by using a rhombohedral layered model in the space group $R \overline{3} m[40]$.

Refined powder X-ray diffraction patterns of the oxides under study are shown in Figure 3.

A few broad peaks appeared in the $2 \Theta$ range of $20^{\circ}-25^{\circ}$ are associated with the presence of a monoclinic phase. Most of the peaks of the trigonal and monoclinic phases overlap. The peaks of the monoclinic phase, which do not coincide with the trigonal phase peaks have substantial anisotropic broadening so that they should be excluded from the Rietveld refinement because cannot be correctly simulated within this method. Comparison of the intensity ratios of $\mathrm{I}(003) / \mathrm{I}(104)$ and $\mathrm{I}(101) / \mathrm{I}(104)$ reflections for the oxides shows that the ratios are nearly the same for LR and LR-Mg (Figure 3a,b), but considerably decreased for LR-Mg(st) (Figure 3c). According to the model calculations, both of these ratios should essentially go down compared to undoped sample LR when any metal will begin occupying the Li-ion layer. On the other hand, these ratios remain very high when the doping metal goes to the transition metal layer, as demonstrated for LR-Mg (Figure 3b). The phase compositions, refined lattice parameters, $R$-factors, and goodness of fit are presented in Table 1. 


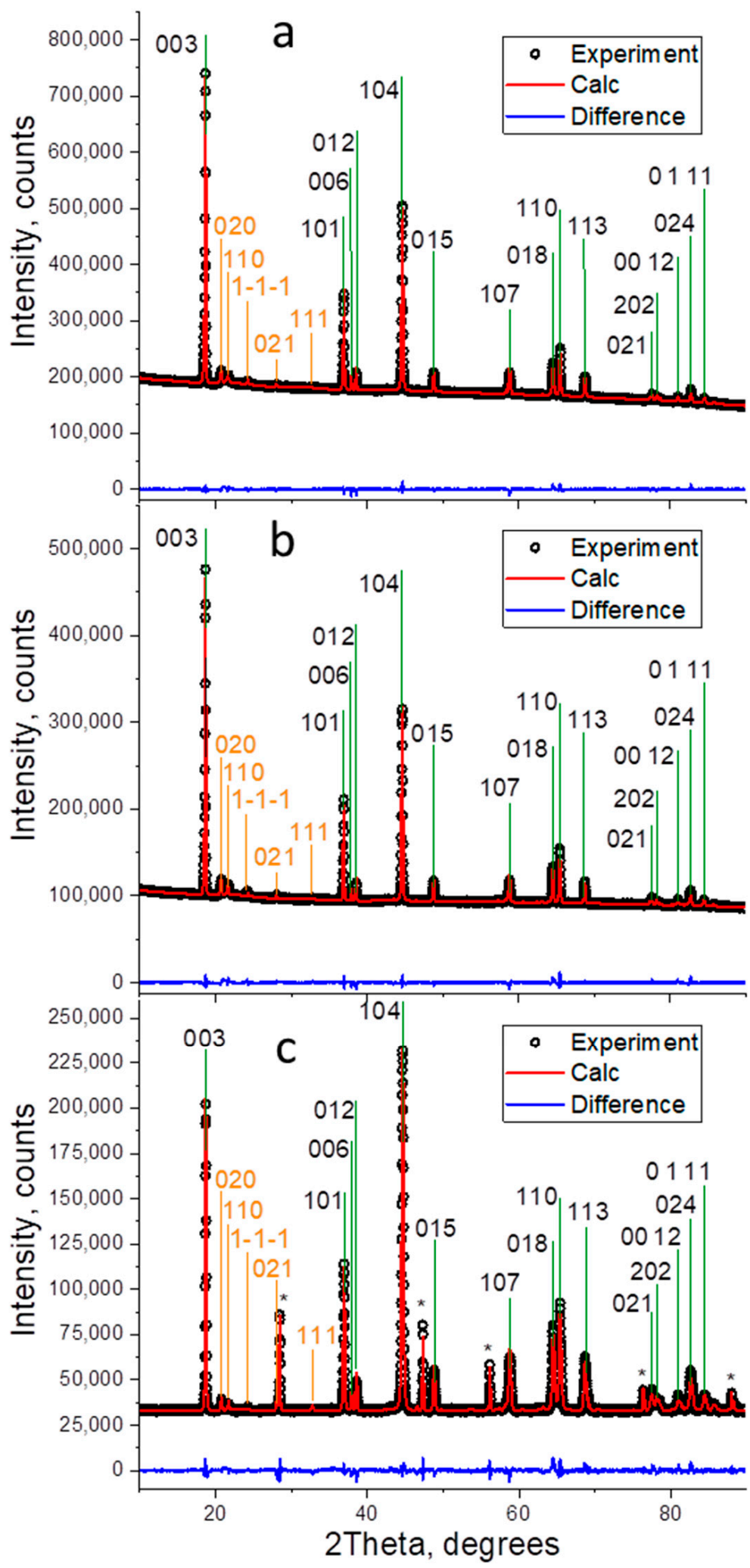

Figure 3. Refined powder X-ray diffraction patterns for materials prepared: (a) LR; (b) LR-Mg; and (c) LR-Mg(st). Diffraction measurements of LR and LR-Mg were carried out with a Ge monochromator; the diffraction pattern of LR-Mg(st) oxide was measured without monochromator using a Si standard reference; the Si lines are designated by asterisks. 
Table 1. Refinement unit cell parameters of LR, LR-Mg, and LR-Mg(st) oxides (space group $R \overline{3} m$ ).

\begin{tabular}{cccccccc}
\hline Sample & $\begin{array}{c}\text { Monoclinic Phase } \\
\text { Portion, } \%\end{array}$ & $\boldsymbol{a}, \AA$ & $\boldsymbol{c}, \AA$ & $\mathbf{A}, \AA^{\mathbf{3}}$ & $\boldsymbol{c} / \boldsymbol{a}$ & Rwp (\%) & Goodness of Fit, S \\
\hline LR & $33(3)$ & $2.84678(6)$ & $14.2180(5)$ & $99.788(5)$ & 4.9944 & 2.81 & 4.12 \\
LR-Mg & $32(1)$ & $2.84911(4)$ & $14.2266(5)$ & $100.011(4)$ & 4.9933 & 0.91 & 2.87 \\
LR-Mg(st) & $31(4)$ & $2.85207(7)$ & $14.2379(4)$ & $100.299(5)$ & 4.9921 & 2.20 & 4.23 \\
\hline
\end{tabular}

The ratios between the amounts of the trigonal and monoclinic phases were evaluated to be equal within the margin of error for all the oxides. The lattice parameters $(a, c)$ and the unit cell volume increase for both Mg-doped samples was compared with the reference oxide LR. The ionic radius of $\mathrm{Mg}^{2+}(0.72 \AA)$ is larger than that of $\mathrm{Co}^{3+}(0.54 \AA)$. This increase in the unit cell parameters can be attributed to the introduction of magnesium at the TM positions. In case of $\mathrm{Mg}$ doping in Li layers, the ionic radii of $\mathrm{Mg}^{2+}$ and $\mathrm{Li}^{+}$ $(0.76 \AA)$ were close to each other. However, when $\mathrm{Mg}^{2+}$ is introduced at lithium sites, some of the TM ions would be partially reduced, accordingly. The reduced TM ions have larger ionic radii than those at higher oxidation states; this also should lead to an increase in the unit cell parameters, which was observed for the LR-Mg(st) sample. Moreover, the introduction of magnesium in the TM layers induces an increase in the oxidation number of the neighboring TM ions in layered structures [41], and the corresponding increase in the lattice parameters may not be very large, which is what we actually observed.

The binding energies (BE) and full widths at half maximum (FWHM) of the XP lines of the LR, LR-Mg, and LR-Mg(st) oxides are presented in Table 2.

Table 2. Binding energies/FWHM of XP lines in the spectra of LR, LR-Mg, and LR-Mg(st) oxides.

\begin{tabular}{|c|c|c|c|c|c|c|c|}
\hline Sample & $\begin{array}{c}\text { C1s, Peak } 1 \\
\pm 0.1 \mathrm{eV}\end{array}$ & $\begin{array}{l}\mathrm{Mn} 2 \mathrm{p} 3 \\
\pm 0.3 \mathrm{eV}\end{array}$ & $\begin{array}{c}\text { Co2p3 } \\
\pm 0.2 \mathrm{eV}\end{array}$ & $\begin{array}{l}\text { Ni2p3 } \\
\pm 0.2 \mathrm{eV}\end{array}$ & $\begin{array}{c}\text { Mg1s } \\
\pm 0.2 \mathrm{eV}\end{array}$ & $\begin{array}{c}\text { O1s Peak } 1 \\
\pm 0.2 ~ \\
\ni \mathbf{B}\end{array}$ & $\begin{array}{c}\text { O1s Peak } 2 \\
\pm 0.2{ }_{\ni} \mathrm{B}\end{array}$ \\
\hline LR & 284.9 & 642.0 & 779.9/1.3 & $854.4 / 1.6$ & - & 529.3 & 531.0 \\
\hline LR-Mg(st) & 284.9 & 642.0 & 779.9/1.3 & $854.5 / 1.7$ & 1302.9/1.2 & 529.2 & 531.3 \\
\hline LR-Mg & 284.9 & 642.0 & 779.9/1.3 & $854.8 / 1.9$ & $1302.9 / 1.5$ & 529.1 & 531.3 \\
\hline
\end{tabular}

The binding energies of manganese and cobalt from the $2 \mathrm{p} 3$ regions were identical for all the samples. However, we observed a positive shift and broadening of the XP peak from the $\mathrm{Ni}_{2} \mathrm{p}_{3 / 2}$ region in the spectrum of LR-Mg compared to those peaks in the spectra of $\mathrm{LR}$ and $\mathrm{LR}-\mathrm{Mg}$ (st). In both the $\mathrm{Ni}^{2+}$ and $\mathrm{Ni}^{3+}$ cases, it was difficult to assign a single $\mathrm{BE}$ to the definite chemical state. Nevertheless, the observed phenomenon can be indicative of the appearance or increase in the $\mathrm{Ni}^{3+}$ content in LR-Mg sample [42]. Since we introduced $\mathrm{Mg}^{2+}$ at the $\mathrm{Co}^{3+}$ positions in this sample, charge compensation can occur at the expense of increasing $\mathrm{Ni}^{3+}$ content. On the other hand, the XP spectra of LR-Mg(st) did not show a significant change in the Ni2 $\mathrm{p}_{3 / 2}$ peaks compared to the LR oxide. In this case, as noted above, some TM ions would be instead partially reduced. A similar effect of an increase in the relative ratio of $\mathrm{Ni}^{3+} / \mathrm{Ni}^{2+}$ ions on the surface as a result of a partial substitution of $\mathrm{Mg}$ for $\mathrm{Ni}$ in $\mathrm{LiNi}_{0.6} \mathrm{Co}_{0.2} \mathrm{Mn}_{0.2} \mathrm{O}_{2}$ was observed in [43].

The XRD and XPS data demonstrate different behaviors of Mg-doped oxides and support our assumption that magnesium is introduced at different positions when different synthesis procedures are used.

The oxides were tested in half-cells as cathode materials. Galvanostatic cycling at different current densities and galvanostatic intermittent titration were performed in the range of 2.5-4.7 V. Before cycling, the high-voltage monoclinic phase was activated at a current density of $20 \mathrm{~mA} / \mathrm{g}$, as follows: two cycles in the range of $2.5-4.3 \mathrm{~V}$, two cycles at $2.5-4.5 \mathrm{~V}$, and two cycles at 2.5-4.6 V. The charge-discharge curves and the corresponding differential capacity $(\mathrm{dQ} / \mathrm{dV})$ plots for the samples in the second charge-discharge cycle (2.5-4.3 V) are shown in Figure 4. 

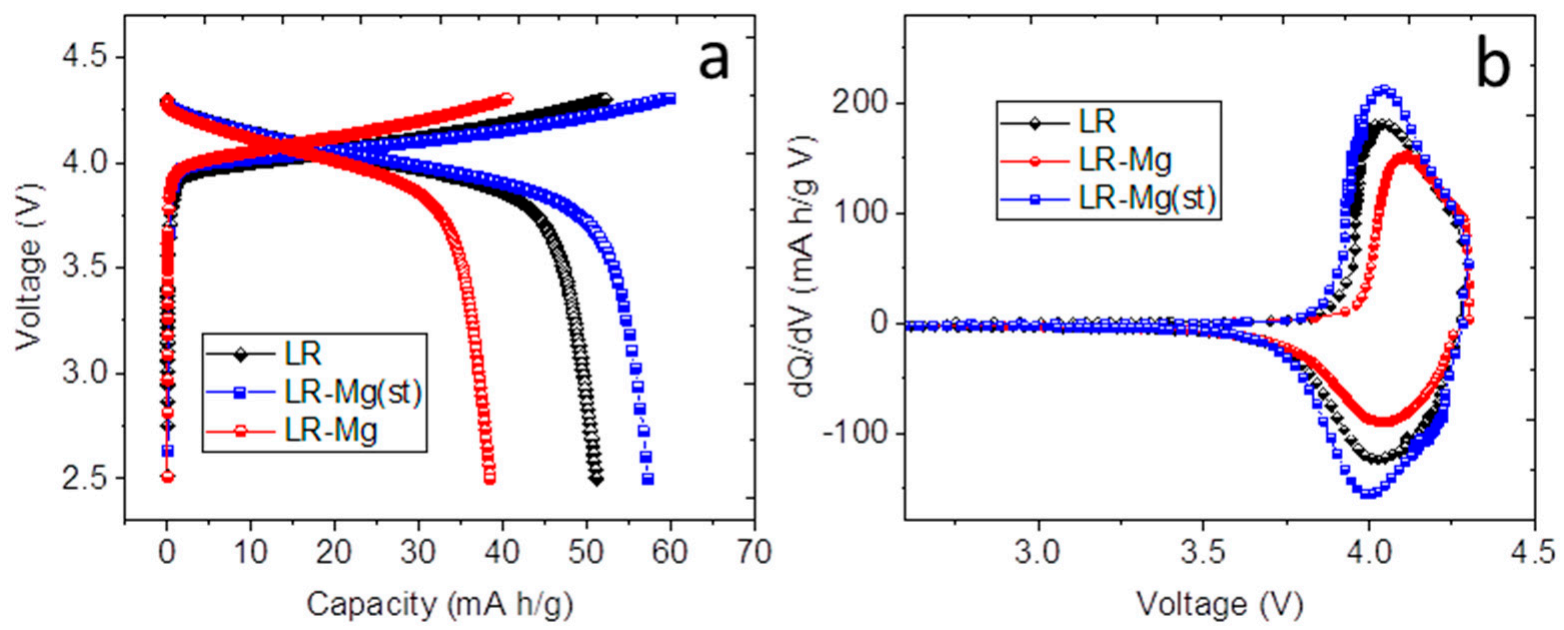

Figure 4. (a) The charge-discharge curves and (b) the corresponding differential capacity (dQ/dV) plots in the second cycle in the potential range of 2.5-4.3 V. Sample names are shown in the figures.

The charge-discharge curves in the range of 2.5-4.3 V (Figure 4a) show different capacities of the samples under study. The electrochemically active species in this voltage range were the trigonal phase $\mathrm{LiMO}_{2}$. The positions of the anodic and cathodic peaks in the corresponding $\mathrm{dQ} / \mathrm{dV}$ plots (Figure $4 \mathrm{~b}$ ) of LR-Mg(st) and LR samples are close to each other, whereas those of LR-Mg are different. This seems to reflect the difference in the compositions of the trigonal phases and indirectly confirms that magnesium enters in the trigonal phase at the TM (Co) positions in LR-Mg oxide. The cause for the lower capacity of LR-Mg oxide charged to $4.3 \mathrm{~V}$ may be the smaller content of cobalt in the trigonal phase in this sample. Possibly, there is an additional reason for this capacity decrease. The authors of [44] were unable to extract chemically all the lithium from the $\mathrm{LiCo}_{0.9} \mathrm{Mg}_{0.1} \mathrm{O}_{2}$ phase and proposed that the presence of $\mathrm{Mg}^{2+}$ ions may lead to a trapping or isolation of some $\mathrm{Co}^{3+}$ ions as ... $\mathrm{Mg}^{2+}-\mathrm{Co}^{3+}-\mathrm{Mg}^{2+} \ldots$, preventing some of the $\mathrm{Co}^{3+}$ ions from participating in the redox process. The same mechanism may be realized in our case. According to the XPS data, $\mathrm{LR}-\mathrm{Mg}$ contains also a larger concentration of $\mathrm{Ni}^{3+}$, which may reduce the specific capacity as well.

The first cycles in the wider potential ranges (up to 4.5 and $4.6 \mathrm{~V}$ ) exhibited the second plateau in the charge-discharge curves and the corresponding peak at $\sim 4.5 \mathrm{~V}$ in the $\mathrm{dQ} / \mathrm{dV}$ plots (Figure 5), which were attributed to the activation of $\mathrm{Li}_{2} \mathrm{MnO}_{3}$ accompanied by lithium and oxygen loss $[6,45]$.

With increases to upper charge voltage, the difference between the $\mathrm{dQ} / \mathrm{dV}$ plots of the samples becomes more apparent. All the samples exhibited a new cathodic peak at 3.3-3.5 V and a small anodic peak (or shoulder) at about 3.5-3.7 V in the $\mathrm{dQ} / \mathrm{dV}$ plots. These peaks were more pronounced for the reference sample LR, whereas both the $\mathrm{Mg}$ doped samples showed more pronounced cathodic peaks representing the reduction of nickel (cobalt) at 3.6-3.7 V.

The electrochemical performance of the samples under study is presented in Figure 6. 

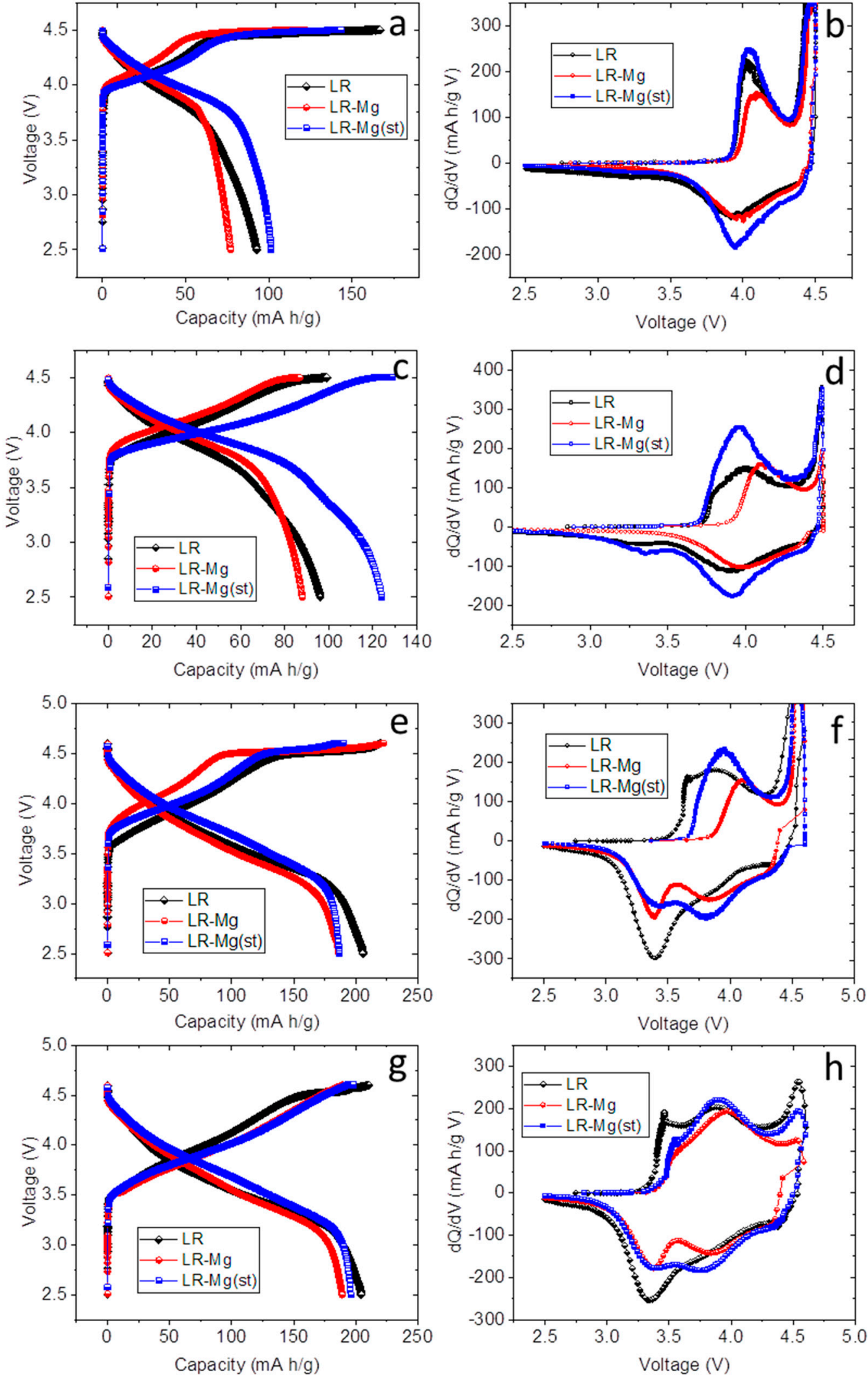

Figure 5. (a,c,e, $\mathbf{g})$ The charge-discharge curves and $(\mathbf{b}, \mathbf{d}, \mathbf{f}, \mathbf{h})$ the corresponding differential capacity $(\mathrm{dQ} / \mathrm{dV})$ plots for the cycles in the potential ranges of $(\mathbf{a}-\mathbf{d}) 2.5-4.5 \mathrm{~V}$ and $(\mathbf{e}-\mathbf{h}) 2.5-4.6 \mathrm{~V}$. The high peaks at $4.5 \mathrm{~V}(\mathbf{b}, \mathbf{f})$ are not shown for clarity. Sample names are shown in the figures. 

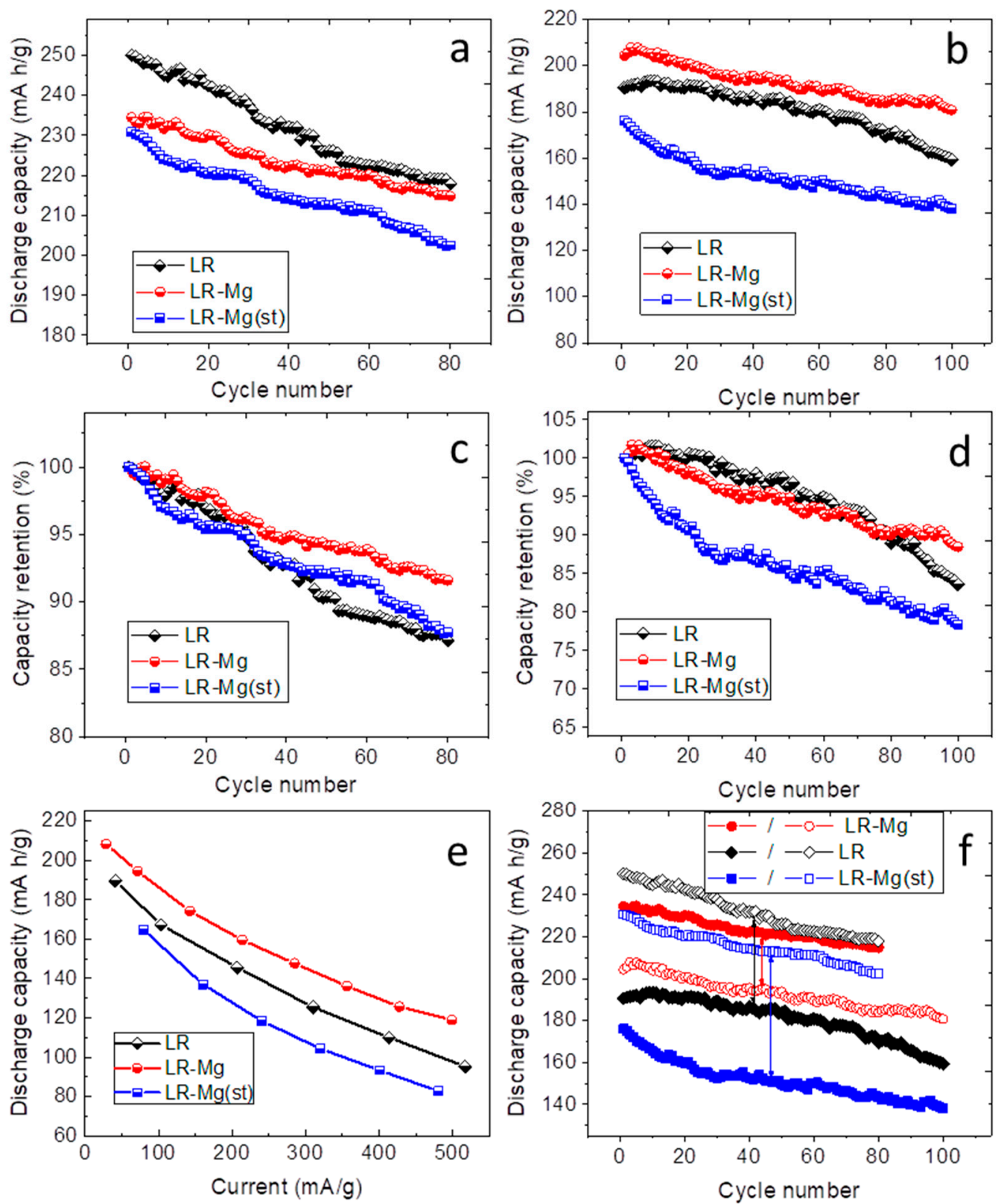

Figure 6. Electrochemical performance of LR, LR-Mg, and LR-Mg(st): discharge capacity as a function of cycle number at the current densities of (a) 20 and (b) $100 \mathrm{~mA} / \mathrm{g}$; capacity retention vs. cycle number at (c) 20 and (d) $100 \mathrm{~mA} / \mathrm{g}$; (e) rate performance; and (f) comparison of sample cycling performance at different current densities (solid and open symbols correspond to the current densities of 20 and $100 \mathrm{~mA} / \mathrm{g}$, respectively).

At the current density of $20 \mathrm{~mA} / \mathrm{g}$ (corresponds to $0.1 \mathrm{C}$ rate), both oxides doped with magnesium show discharge capacities lower than the discharge capacity of the reference sample (Figure 6a). At the current density of $100 \mathrm{~mA} / \mathrm{g}$ (Figure 6b), the discharge capacity of LR-Mg was higher than that of LR, whereas the discharge capacity of LR-Mg(st) considerably decreased compared with the reference sample. LR-Mg also demonstrates better cyclability at both current densities, which is clearly seen in the capacity retention plots (Figure 6c,d). The cyclability of LR-Mg(st) oxide is nearly the same as that of LR. The rate performance of LR-Mg(st) is also comparable to that of LR, whereas the dependence of the discharge capacity on the current density for LR-Mg is somewhat better than that of LR (Figure 6e). Figure $6 \mathrm{f}$ shows a comparison of the discharge plots of the samples at different current densities. One can see that an increase in the current density has the greatest impact 
on LR-Mg(st) cycling, and the least impact on LR-Mg cycling. One reason for this behavior is the better kinetics in the latter sample. To check this assumption, galvanostatic intermittent titration was performed for all the samples during discharge at a current density of $100 \mathrm{~mA} / \mathrm{g}$ to determine the lithium-ion diffusion coefficient $\left(D_{\mathrm{Li+}}\right)$ and the polarization $\left(R_{\mathrm{pol}}\right)$ and ohmic $\left(R_{\mathrm{ohm}}\right)$ resistance values [34-36]. The GITT measurements were carried out at intervals of 10 cycles. The $D_{L i+}$ of the oxides as a function of the cell voltage derived for the 11-th and 77-th discharge titration cycles are shown in Figure 7a.
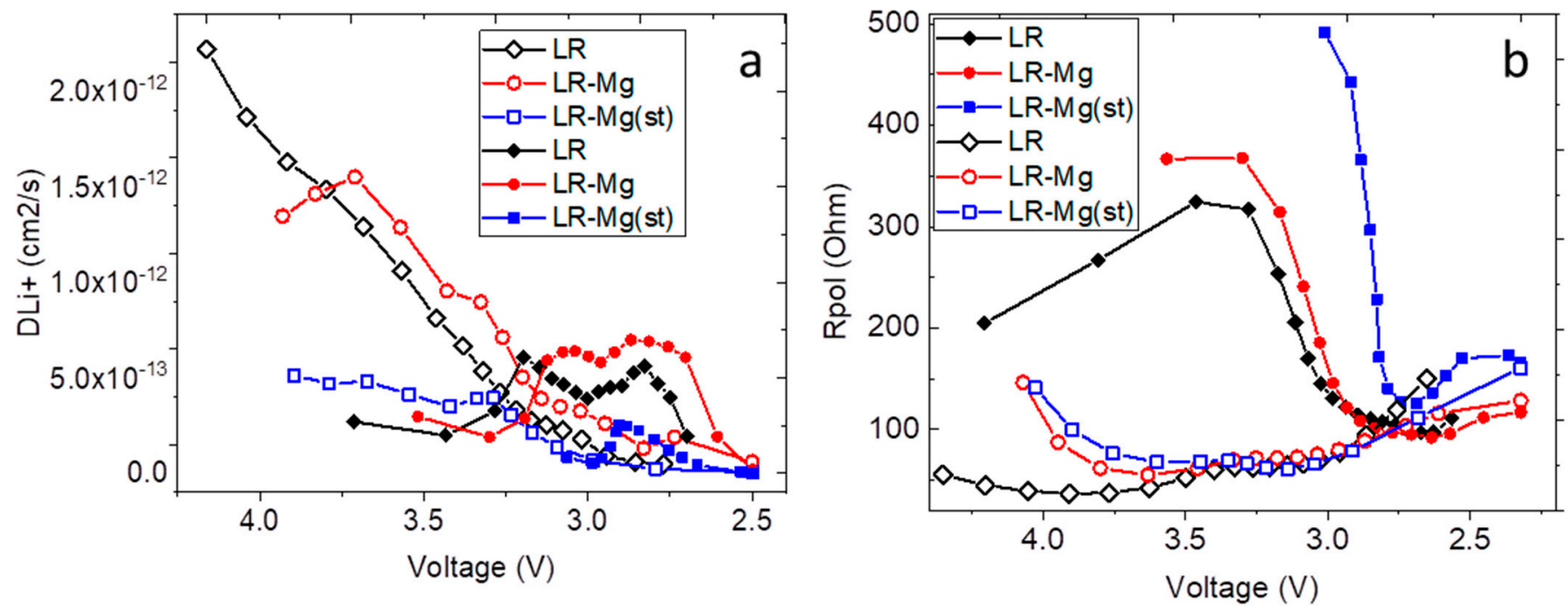

Figure 7. Variation of (a) $D_{L i+}$ and (b) $R_{\text {pol }}$ as a function of cell voltage for different cycles determined by GITT. Open and solid symbols designate the data derived from 11-th and 77-th cycles, respectively. Sample names are shown in the figures.

In both cycles, LR-Mg shows the highest lithium-ion diffusion coefficient, and the $D_{\mathrm{Li}+}$ of LR-Mg(st) was the lowest one. The polarization resistance shows the maximal values also for $\mathrm{LR}-\mathrm{Mg}(\mathrm{st})$. At the beginning, $D_{L i+}$ decreases during the discharge process (Figure 7a, open symbols); and $D_{L i+}$ passes through maxima with increasing cycle number (Figure $7 \mathrm{a}$, solid symbols). The maximum positions roughly corresponded to new peaks appearing in $\mathrm{dQ} / \mathrm{dV}$ plots in the course of cycling (Figure 8).

The cathodic peaks in the range of 2.8-3.2 V were very broad and can be assigned to different redox species. The overlapping peaks can be interpreted as cathodic peaks due to the reduction of nickel (cobalt) and the peak occurred due to the reduction of manganese-containing redox species [46]. In the literature, the appearance of the reduction peak at a lower potential is commonly associated with an internal phase transition to a spinel-like phase due to the migration of transition metal ions into vacant sites of the lithium layers during the charging process, which leads to voltage decay in the course of cycling [47-50]. The cathodic peaks shifted to low voltage in the $\mathrm{dQ} / \mathrm{dV}$ plots with cycling. This shift was the lowest for LR-Mg and the greatest for LR-Mg(st). At the same time, the new phase seems to contribute to the overall discharge capacity. Simultaneously with the appearance of the new cathodic peak, we observed a small anodic peak at about 3.0-3.3 V for LR and LR-Mg oxides. However, this anodic peak was absent in the dQ/dV plots of LR-Mg(st) at the current density of $100 \mathrm{~mA} / \mathrm{g}$. A comparison of the dQ/dV plots of all the samples in the 60th cycle at the current density of $20 \mathrm{~mA} / \mathrm{g}$ are presented in Figure $8 \mathrm{~d}$. As is seen, the $\mathrm{dQ} / \mathrm{dV}$ plots are similar, and a shoulder near 3.0-3.3 V appears in the anodic $\mathrm{dQ} / \mathrm{dV}$ curve of LR-Mg(st) as well. This indicates that kinetic hindrance exists for oxidation of manganese-containing species in LR-Mg(st) oxide, which decreases the reversibility of the redox reaction of the species. The specific discharge capacity of LR$\mathrm{Mg}$ (st) (Figure 6a,b) is, indeed, significantly lower than that of LR and LR-Mg at the higher current density. The authors of [46] studied the Li-rich oxide $\mathrm{Li}_{1.2} \mathrm{Ni}_{0.15} \mathrm{Co}_{0.1} \mathrm{Mn}_{0.55} \mathrm{O}_{2}$ 
[0.5 Li $\left(\mathrm{Ni}_{0.375} \mathrm{Co}_{0.25} \mathrm{Mn}_{0.375}\right) \mathrm{O}_{2} \cdot 0.5 \mathrm{Li}_{2} \mathrm{MnO}_{3}$ ] by a combination of XRD, TEM, conventional and time resolved in situ XAS experiments, and GITT techniques. Based on the EXAFS analysis and changes in the Debye-Waller factors, the authors have shown that Mn sites had much poorer reaction kinetics both before and after the initial activation of $\mathrm{Li}_{2} \mathrm{MnO}_{3}$ compared to $\mathrm{Ni}$ and $\mathrm{Co}$ in this Li-rich oxide. They deduced also that the severe local structural changes in the Mn-O coordination shell observed during the initial delithiation can be mainly attributed to the $\mathrm{Li}_{2} \mathrm{MnO}_{3}$ component of the Li-rich material as a result of the elimination of $\mathrm{Li} / \mathrm{Mn}$ ordering in $\mathrm{Li}_{2} \mathrm{MnO}_{3}$ and/or the oxygen release accompanied with lithium extraction. Taking the above into account, we can assume from our results that $\mathrm{Mg}^{2+}$ substitutes for lithium ions in the monoclinic phase of LR-Mg(st) to a greater extent than in the trigonal phase of this sample. If magnesium exists predominantly in the monoclinic phase, which transforms after activation into the manganese-containing redox species, the negative effect of the $\mathrm{Mg}$ doping on the kinetics of $\mathrm{LR}-\mathrm{Mg}(\mathrm{st})$ sample (oxidation in the range of 3.0-3.3 V) is understandable. The presence of $\mathrm{Mg}^{2+}$ ions (additional charge) in the $\mathrm{Li}$ layers may hinder the re-insertion of $\mathrm{Li}^{+}$ions during discharge, which results in decreasing the lithium-ion diffusion coefficient and increasing the polarization resistance, in the range of about $3 \mathrm{~V}$. On the other hand, the substitution of $\mathrm{Mg}$ for TM in LR-Mg oxide slows the structural changes in the initial cycles and stabilizes these Li- and Mn-rich layered cathode materials.
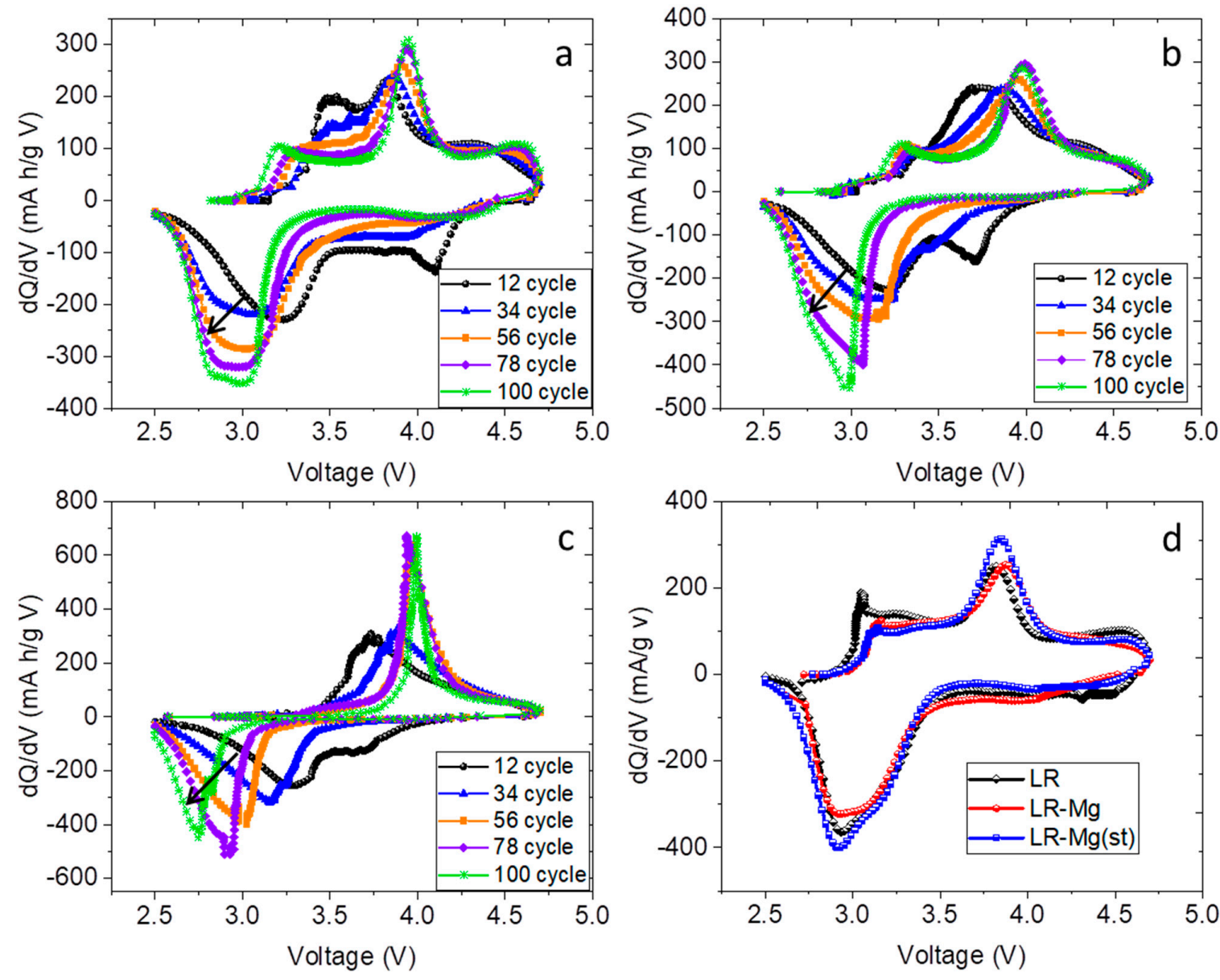

Figure 8. Differential capacity plots (dQ/dV) of the samples (a) LR; (b) LR-Mg; and (c) LR-Mg(st) in different charge-discharge cycles at the current density of $100 \mathrm{~mA} / \mathrm{g}$ and (d) comparison of $\mathrm{dQ} / \mathrm{dV}$ plots for the samples in the 60th cycle at the current density of $20 \mathrm{~mA} / \mathrm{g}$ (samples names are shown in this figure). 


\section{Conclusions}

Li-rich layered oxide $\mathrm{Li}_{1.2} \mathrm{Mn}_{0.54} \mathrm{Ni}_{0.13} \mathrm{Co}_{0.13} \mathrm{O}_{2}$ was doped with magnesium at different positions (TM and $\mathrm{Li}$ ) using different procedures for $\mathrm{Mg}$ introduction. The results of XRD with Rietveld refinement, scanning and transmission electron microscopy with local EDX analysis, selected-area electron diffractions, X-ray photoelectron spectroscopy, charge-discharge tests, and galvanostatic intermittent titration showed that introduction of $\mathrm{Mg}$ in the TM layers is preferable to the presence of $\mathrm{Mg}$ at $\mathrm{Li}$ positions in terms of electrochemical performance. The sample doped with $\mathrm{Mg}$ at the TM positions (LR-Mg) shows better cyclability and an even higher discharge capacity than the reference (undoped) sample LR, at a higher current density. The poor electrochemical properties of the samples doped with $\mathrm{Mg}$ at $\mathrm{Li}$ positions ( $\mathrm{LR}-\mathrm{Mg}(\mathrm{st})$ ) were due to kinetic hindrance of oxidation of manganese-containing species formed after activation of $\mathrm{Li}_{2} \mathrm{MnO}_{3}$ component of the composite oxide. LR-Mg(st) demonstrates the lowest lithium-ion diffusion coefficient and the greatest polarization resistance compared to LR and LR-Mg. Thus, doping with $\mathrm{Mg}$ has a site-dependent effect on the electrochemical behavior of $\mathrm{Li}$ - and $\mathrm{Mn}$-rich layered cathode materials.

Supplementary Materials: The following are available online at https://www.mdpi.com/article/ 10.3390/nano12010156/s1, Table S1: ICP-MS analysis results, Figure S1: Particle size distributions for LR, LR-Mg, and LR-Mg(st) oxides: (a) differential distribution; (b) integral distribution, Figure S2: Element distribution EDX maps of LR-Mg and LR-Mg(st) oxides (see designations on the figures).

Author Contributions: Conceptualization, I.E. and E.M.; methodology, E.M.; synthesis, A.M., L.P. and Y.P.; SEM and TEM studies, A.M. and V.V.; XRD analysis, A.M. and A.G.; electrochemical measurements, A.R., Y.K. and Y.P.; data analysis, E.M., L.P. and A.M; writing-original draft preparation, E.M.; writing-review and editing, I.E., E.M., L.P. and A.M.; visualization, E.M., L.P., A.M. and Y.P.; supervision, I.E. and E.M.; project administration, E.M.; funding acquisition, E.M. All authors have read and agreed to the published version of the manuscript.

Funding: This research was funded by the Russian Science Foundation, grant number 20-13-00423.

Acknowledgments: The compound's characterization was performed with the financial support from Ministry of Science and Higher Education of the Russian Federation using the equipment of the Joint Research Center of the Kurnakov Institute (SEM, XPS, XRD, and BET studies) and the Center for molecular composition studies of INEOS RAS (Powder XRD).

Conflicts of Interest: The authors declare no conflict of interest.

\section{References}

1. U.S. Department of Energy. Energy Storage Grand Challenge. In Energy Storage Market Report 2020; U.S. Department of Energy: Washington, DC, USA, 2020; p. 65.

2. Berg, E.J.; Villevieille, C.; Streich, D.; Trabesinger, S.; Novák, P. Rechargeable Batteries: Grasping for the Limits of Chemistry. J. Electrochem. Soc. 2015, 162, A2468-A2475. [CrossRef]

3. Schipper, F.; Nayak, P.; Erickson, E.; Amalraj, S.; Srur-Lavi, O.; Penki, T.; Talianker, M.; Grinblat, J.; Sclar, H.; Breuer, O.; et al. Study of Cathode Materials for Lithium-Ion Batteries: Recent Progress and New Challenges. Inorganics 2017, 5, 32. [CrossRef]

4. Johnson, C.S.; Kim, J.-S.; Lefief, C.; Li, N.; Vaughey, J.T.; Thackeray, M.M. The significance of the Li2MnO3 component in 'composite' $\mathrm{xLi}_{2} \mathrm{MnO}_{3} \cdot(1-\mathrm{x}) \mathrm{LiMn}_{0.5} \mathrm{Ni}_{0.5} \mathrm{O}_{2}$ electrodes. Electrochem. Commun. 2004, 6, 1085-1091. [CrossRef]

5. Thackeray, M.M.; Kang, S.-H.; Johnson, C.S.; Vaughey, J.T.; Benedek, R.; Hackney, S.A. $\mathrm{Li}_{2} \mathrm{MnO}_{3}$-stabilized LiMO $2\left(\mathrm{M}=\mathrm{Mn}_{2} \mathrm{Ni}_{\text {, }}\right.$ Co) electrodes for lithium-ion batteries. J. Mater. Chem. 2007, 17, 3112-3125. [CrossRef]

6. Koga, H.; Croguennec, L.; Ménétrier, M.; Douhil, K.; Belin, S.; Bourgeois, L.; Suard, E.; Weill, F.; Delmas, C. Reversible Oxygen Participation to the Redox Processes Revealed for $\mathrm{Li}_{1.20} \mathrm{Mn}_{0.54} \mathrm{Co}_{0.13} \mathrm{Ni}_{0.13} \mathrm{O}_{2}$. J. Electrochem. Soc. 2013, 160, 786-792. [CrossRef]

7. Divakaran, A.M.; Minakshi, M.; Bahri, P.A.; Paul, S.; Kumari, P.; Divakaran, A.M.; Manjunatha, K.N. Rational design on materials for developing next generation lithium-ion secondary battery. Prog. Solid State Chem. 2021, 62, 100298. [CrossRef]

8. Assat, G.; Tarascon, J.-M. Fundamental understanding and practical challenges of anionic redox activity in Li-ion batteries. Nat. Energy 2018, 3, 373-386. [CrossRef]

9. Xie, Y.; Saubanère, M.; Doublet, M.-L. Requirements for reversible extra-capacity in Li-rich layered oxides for Li-ion batteries. Energy Environ. Sci. 2017, 10, 266-274. [CrossRef]

10. Abakumov, A.M.; Fedotov, S.S.; Antipov, E.V.; Tarascon, J.-M. Solid state chemistry for developing better metal-ion batteries. Nat. Commun. 2020, 11, 4976. [CrossRef] 
11. Seo, D.-H.; Lee, J.; Urban, A.; Malik, R.; Kang, S.; Ceder, G. The structural and chemical origin of the oxygen redox activity in layered and cation-disordered Li-excess cathode materials. Nat. Chem. 2016, 8, 692-697. [CrossRef]

12. McCalla, E.; Abakumov, A.M.; Saubanère, M.; Foix, D.; Berg, E.J.; Rousse, G.; Doublet, M.-L.; Gonbeau, D.; Novák, P.; Van Tendeloo, G.; et al. Visualization of O-O peroxo-like dimers in high-capacity layered oxides for Li-ion batteries. Science 2015, 350, 1516-1521. [CrossRef] [PubMed]

13. Li, X.; Qiao, Y.; Guo, S.; Xu, Z.; Zhu, H.; Zhang, X.; Yuan, Y.; He, P.; Ishida, M.; Zhou, H. Direct Visualization of the Reversible $\mathrm{O}^{2-} / \mathrm{O}^{-}$Redox Process in Li-Rich Cathode Materials. Adv. Mater. 2018, 30, 1705197. [CrossRef] [PubMed]

14. Sharifi-Asl, S.; Lu, J.; Amine, K.; Shahbazian-Yassar, R. Oxygen Release Degradation in Li-Ion Battery Cathode Materials: Mechanisms and Mitigating Approaches. Adv. Energy Mater. 2019, 9, 1900551. [CrossRef]

15. Chen, H.; Islam, M.S. Lithium Extraction Mechanism in Li-Rich $\mathrm{Li}_{2} \mathrm{MnO}_{3}$ Involving Oxygen Hole Formation and Dimerization. Chem. Mater. 2016, 28, 6656-6663. [CrossRef]

16. Croy, J.R.; Gallagher, K.G.; Balasubramanian, M.; Long, B.R.; Thackeray, M.M. Quantifying Hysteresis and Voltage Fade in xLi ${ }_{2} \mathrm{MnO}_{3} \bullet(1-\mathrm{x}) \mathrm{LiMn}_{0.5} \mathrm{Ni}_{0.5} \mathrm{O}_{2}$ Electrodes as a Function of $\mathrm{Li}_{2} \mathrm{MnO}_{3}$ Content. J. Electrochem. Soc. 2014, 161, A318-A325. [CrossRef]

17. Dogan, F.; Long, B.R.; Croy, J.R.; Gallagher, K.G.; Iddir, H.; Russell, J.T.; Balasubramanian, M.; Key, B. Re-entrant Lithium Local Environments and Defect Driven Electrochemistry of Li- and Mn-Rich Li-Ion Battery Cathodes. J. Am. Chem. Soc. 2015, 137, 2328-2335. [CrossRef]

18. Myung, S.-T.; Izumi, K.; Komaba, S.; Yashiro, H.; Bang, H.J.; Sun, Y.-K.; Kumagai, N. Functionality of Oxide Coating for $\mathrm{Li}\left[\mathrm{Li}_{0.05} \mathrm{Ni}_{0.4} \mathrm{Co}_{0.15} \mathrm{Mn}_{0.4}\right] \mathrm{O}_{2}$ as Positive Electrode Materials for Lithium-Ion Secondary Batteries. J. Phys. Chem. C 2007, 111, 4061-4067. [CrossRef]

19. Qiu, B.; Zhang, M.; Wu, L.; Wang, J.; Xia, Y.; Qian, D.; Liu, H.; Hy, S.; Chen, Y.; An, K.; et al. Gas-solid interfacial modification of oxygen activity in layered oxide cathodes for lithium-ion batteries. Nat. Commun. 2016, 7, 12108. [CrossRef]

20. Zhu, Z.; Yu, D.; Yang, Y.; Su, C.; Huang, Y.; Dong, Y.; Waluyo, I.; Wang, B.; Hunt, A.; Yao, X.; et al. Gradient Li-rich oxide cathode particles immunized against oxygen release by a molten salt treatment. Nat. Energy 2019, 4, 1049-1058. [CrossRef]

21. Oh, P.; Yun, J.; Park, S.; Nam, G.; Liu, M.; Cho, J. Recent Advances and Prospects of Atomic Substitution on Layered Positive Materials for Lithium-Ion Battery. Adv. Energy Mater. 2021, 11, 2003197. [CrossRef]

22. Phattharasupakun, N.; Geng, C.; Johnson, M.B.; Väli, R.; Liu, A.; Liu, Y.; Sawangphruk, M.; Dahn, J.R. Impact of Al Doping and Surface Coating on the Electrochemical Performances of Li-Rich Mn-Rich $\mathrm{Li}_{1.11} \mathrm{Ni}_{0.33} \mathrm{Mn}_{0.56} \mathrm{O}_{2}$ Positive Electrode Material J. Electrochem. Soc. 2020, 167, 120531. [CrossRef]

23. Zhai, Y.; Zhang, J.; Zhang, H.; Liu, X.; Wang, C.-W.; Sun, L.; Liu, X. The Synergic Effects of Zr Doping and Li $2 \mathrm{TiO}_{3}$ Coating on the Crystal Structure and Electrochemical Performances of Li-Rich $\mathrm{Li}_{1.2} \mathrm{Ni}_{0.2} \mathrm{Mn}_{0.6} \mathrm{O}_{2}$. J. Electrochem. Soc. 2019, 166, A1323-A1329. [CrossRef]

24. Ning, F.; Li, B.; Song, J.; Zuo, Y.; Shang, H.; Zhao, Z.; Yu, Z.; Chu, W.; Zhang, K.; Feng, G.; et al. Inhibition of oxygen dimerization by local symmetry tuning in Li-rich layered oxides for improved stability. Nat. Commun. 2020, 11, 4973. [CrossRef] [PubMed]

25. Nayak, P.K.; Erickson, E.M.; Schipper, F.; Penki, T.R.; Munichandraiah, N.; Adelhelm, P.; Sclar, H.; Amalraj, F.; Markovsky, B.; Aurbach, D. Review on Challenges and Recent Advances in the Electrochemical Performance of High Capacity Li- and Mn-Rich Cathode Materials for Li-Ion Batteries. Adv. Energy Mater. 2018, 8, 1702397. [CrossRef]

26. Kong, F.; Longo, R.C.; Yeon, D.-H.; Yoon, J.; Park, J.-H.; Liang, C.; KC, S.; Zheng, Y.; Doo, S.-G.; Cho, K. Multivalent Li-Site Doping of Mn Oxides for Li-Ion Batteries. J. Phys. Chem. C 2015, 119, 21904-21912. [CrossRef]

27. Liu, W.; Oh, P.; Liu, X.; Myeong, S.; Cho, W.; Cho, J. Countering Voltage Decay and Capacity Fading of Lithium-Rich Cathode Material at $60{ }^{\circ} \mathrm{C}$ by Hybrid Surface Protection Layers. Adv. Energy Mater. 2015, 5, 1500274. [CrossRef]

28. Xu, H.; Deng, S.; Chen, G. Improved electrochemical performance of $\mathrm{Li}_{1.2} \mathrm{Mn}_{0.54} \mathrm{Ni}_{0.13} \mathrm{Co}_{0.13} \mathrm{O}_{2}$ by $\mathrm{Mg}$ doping for lithium ion battery cathode material. J. Mater. Chem. A 2014, 2, 15015-15021. [CrossRef]

29. Nayak, P.K.; Grinblat, J.; Levi, E.; Levi, M.; Markovsky, B.; Aurbach, D. Understanding the influence of Mg doping for the stabilization of capacity and higher discharge voltage of Li- and Mn-rich cathodes for Li-ion batteries. Phys. Chem. Chem. Phys. 2017, 19, 6142-6152. [CrossRef]

30. Wang, D.; Huang, Y.; Huo, Z.; Chen, L. Synthesize and electrochemical characterization of Mg-doped Li-rich layered $\mathrm{Li}\left[\mathrm{Li}_{0.2} \mathrm{Ni}_{0.2} \mathrm{Mn}_{0.6}\right] \mathrm{O}_{2}$ cathode material. Electrochim. Acta 2013, 107, 461-466. [CrossRef]

31. Xiang, Y.; Li, J.; Wu, X.; Liu, Z.; Xiong, L.; He, Z.; Yin, Z. Synthesis and electrochemical characterization of Mg-doped Li-rich Mn-based cathode material. Ceram. Int. 2016, 42, 8833-8838. [CrossRef]

32. Ni, J.; Zhao, Y.; Chen, J.; Gao, L.; Lu, L. Site-dependent electrochemical performance of Mg doped LiFePO 4 . Electrochem. Commun. 2014, 44, 4-7. [CrossRef]

33. Makhonina, E.V.; Pechen, L.S.; Volkov, V.V.; Rumyantsev, A.M.; Koshtyal, Y.M.; Dmitrienko, A.O.; Politov, Y.A.; Pervov, V.S.; Eremenko, I.L. Synthesis, microstructure, and electrochemical performance of Li-rich layered oxide cathode materials for Li-ion batteries. Russ. Chem. Bull. 2019, 68, 301-312. [CrossRef]

34. Weppner, W.; Huggins, R.A. Determination of the Kinetic Parameters of Mixed-Conducting Electrodes and Application to the System Li3Sb. J. Electrochem. Soc. 1977, 124, 1569-1578. [CrossRef]

35. Wen, C.J.; Boukamp, B.A.; Huggins, R.A.; Weppner, W. Thermodynamic and Mass Transport Properties of "LiAl”. J. Electrochem. Soc. 1979, 126, 2258-2266. [CrossRef] 
36. Pechen, L.; Makhonina, E.; Volkov, V.; Rumyantsev, A.; Koshtyal, Y.; Politov, Y.; Pervov, V.; Eremenko, I. Investigation of Capacity Fade and Voltage Decay in Li-Rich Cathode Materials with Different Phase Composition. In Proceedings of the 11th International Conference on Nanomaterials-Research \& Application, Hotel Voronez I, Brno, Czech Republic, 16-18 October 2019; pp. 144-149.

37. Koga, H.; Croguennec, L.; Ménétrier, M.; Mannessiez, P.; Weill, F.; Delmas, C. Different oxygen redox participation for bulk and surface: A possible global explanation for the cycling mechanism of $\mathrm{Li}_{1.20} \mathrm{Mn}_{0.54} \mathrm{Co} 0.13 \mathrm{Ni}_{0.13} \mathrm{O}_{2}$. J. Power Sources 2013, 236, 250-258. [CrossRef]

38. Makhonina, E.V.; Maslennikova, L.S.; Volkov, V.V.; Medvedeva, A.E.; Rumyantsev, A.M.; Koshtyal, Y.M.; Maximov, M.Y.; Pervov, V.S.; Eremenko, I.L. Li-rich and Ni-rich transition metal oxides: Coating and core-shell structures. Appl. Surf. Sci. 2019, 474, 25-33. [CrossRef]

39. Muhammad, S.; Kim, H.; Kim, Y.; Kim, D.; Song, J.H.; Yoon, J.; Park, J.-H.; Ahn, S.-J.; Kang, S.-H.; Thackeray, M.M.; et al. Evidence of reversible oxygen participation in anomalously high capacity Li- and Mn-rich cathodes for Li-ion batteries. Nano Energy 2016, 21, 172-184. [CrossRef]

40. Armstrong, A.R.; Paterson, A.J.; Dupré, N.; Grey, C.P.; Bruce, P.G. Structural Evolution of Layered $\mathrm{Li}_{x} \mathrm{Mn}_{y} \mathrm{O}_{2}$ : Combined Neutron, NMR, and Electrochemical Study. Chem. Mater. 2007, 19, 1016-1023. [CrossRef]

41. Levasseur, S.; Ménétrier, M.; Delmas, C. On the Dual Effect of $\mathrm{Mg}$ Doping in $\mathrm{LiCoO}_{2}$ and $\mathrm{Li}_{1+\delta} \mathrm{CoO}_{2}$ : Structural, Electronic Properties, and ${ }^{7}$ Li MAS NMR Studies. Chem. Mater. 2002, 14, 3584-3590. [CrossRef]

42. Grosvenor, A.P.; Biesinger, M.C.; Smart, R.S.C.; McIntyre, N.S. New interpretations of XPS spectra of nickel metal and oxides. Surf. Sci. 2006, 600, 1771-1779. [CrossRef]

43. Huang, Z.; Wang, Z.; Zheng, X.; Guo, H.; Li, X.; Jing, Q.; Yang, Z. Effect of Mg doping on the structural and electrochemical performance of $\mathrm{LiNi}_{0.6} \mathrm{Co}_{0.2} \mathrm{Mn}_{0.2} \mathrm{O}_{2}$ cathode materials. Electrochim. Acta 2015, 182, 795-802. [CrossRef]

44. Venkatraman, S.; Manthiram, A. Comparison of the phase relationships of chemically delithiated layered $\mathrm{LiCoMO}(\mathrm{M}=\mathrm{Al}$ and $\mathrm{Mg}$ ) oxides. Solid State Ionics 2005, 176. [CrossRef]

45. Boulineau, A.; Simonin, L.; Colin, J.-F.; Bourbon, C.; Patoux, S. First Evidence of Manganese-Nickel Segregation and Densification upon Cycling in Li-Rich Layered Oxides for Lithium Batteries. Nano Lett. 2013, 13, 3857-3863. [CrossRef] [PubMed]

46. Yu, X.; Lyu, Y.; Gu, L.; Wu, H.; Bak, S.-M.; Zhou, Y.; Amine, K.; Ehrlich, S.N.; Li, H.; Nam, K.-W.; et al. Understanding the Rate Capability of High-Energy-Density Li-Rich Layered $\mathrm{Li}_{1.2} \mathrm{Ni}_{0.15} \mathrm{Co}_{0.1} \mathrm{Mn}_{0.55} \mathrm{O}_{2}$ Cathode Materials. Adv. Energy Mater. 2014, 4, 1300950. [CrossRef]

47. Rozier, P.; Tarascon, J.M. Review_Li-Rich Layered Oxide Cathodes for Next-Generation Li-Ion Batteries: Chances and Challenges. J. Electrochem. Soc. 2015, 162, A2490-A2499. [CrossRef]

48. Xu, B.; Fell, C.R.; Chi, M.; Meng, Y.S. Identifying surface structural changes in layered Li-excess nickel manganese oxides in high voltage lithium ion batteries: A joint experimental and theoretical study. Energy Environ. Sci. 2011, 4, 2223. [CrossRef]

49. Croy, J.R.; Kim, D.; Balasubramanian, M.; Gallagher, K.; Kang, S.-H.; Thackeray, M.M. Countering the Voltage Decay in High Capacity $x \mathrm{Li}_{2} \mathrm{MnO}_{3} \bullet(1-\mathrm{x}) \mathrm{LiMO}_{2}$ Electrodes $(\mathrm{M}=\mathrm{Mn}, \mathrm{Ni}, \mathrm{Co})$ for $\mathrm{Li}^{+}$-Ion Batteries. J. Electrochem. Soc. 2012, 159, A781-A790. [CrossRef]

50. Gu, M.; Belharouak, I.; Zheng, J.; Wu, H.; Xiao, J.; Genc, A.; Amine, K.; Thevuthasan, S.; Baer, D.R.; Zhang, J.-G.; et al. Formation of the Spinel Phase in the Layered Composite Cathode Used in Li-Ion Batteries. ACS Nano 2013, 7, 760-767. [CrossRef] 